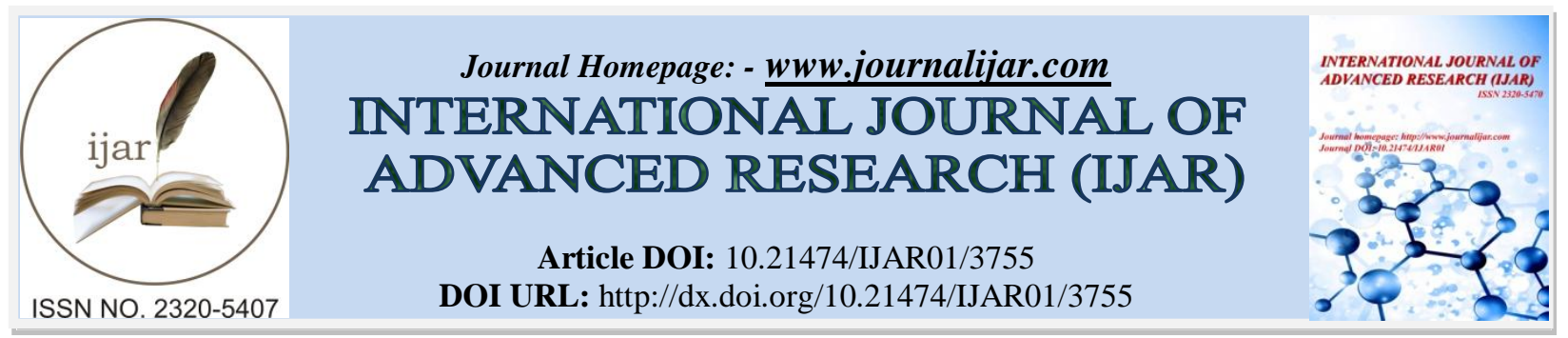

RESEARCH ARTICLE

\title{
A COMPARATIVE ANALYSIS OF FINANCIAL RATIOS WITH SPECIAL REFERENCE TO TATA STEEL (2014 AND 2015).
}

Assistant Professor, Sydenham Institute of Management Studies, Research and Entrepreneurship Education, Mumbai, India.

\section{Manuscript Info}

\section{Manuscript History}

Received: 16 January 2017

Final Accepted: 10 February 2017

Published: March 2017

Key words:-

TATA, Ratio, Liquidity, Profitability, leverage

\section{Abstract}

In 2014, the world crude steel production reached 1665 million tonnes (mt) and showed a growth of $1 \%$ over 2013. China remained the world's largest crude steel producer in $2014(823 \mathrm{mt})$ followed by Japan $(110.7 \mathrm{mt})$, the USA $(88.2 \mathrm{mt})$ and India $(86.5 \mathrm{mt})$ at the $4^{\text {th }}$ position. WSA has projected Indian steel demand to grow by $6.2 \%$ in 2015 and by $7.3 \%$ in 2016 as compared to global steel use growth of $0.5 \%$ and $1.4 \%$ respectively (Ministry of Steel, Government of India 2016).

Established in 1907 as Asia's first integrated private sector steel company, Tata Steel Group is among the top-ten global steel companies with an annual crude steel capacity of over 29 million tonnes per annum. It is now the world's second-most geographically-diversified steel producer, with operations in 26 countries and a commercial presence in over 50 countries. The Tata Steel Group, with a turnover of Rs. 1, 48,614 crores in FY 14, has over 80,000 employees across five continents and is a Fortune 500 company (Tata Steel 2016).

All research used for this paper will be secondary information. Secondary information was taken from Tatasteel.com. The method of analysis is through ratios. The study concentrates on profitability ratios and concentrates on company's two-year growth.

Liquidity ratios affect profitability as they have a positive direct relationship. If liquidity is low, profitability will be affected negatively. If Liquidity is high, profitability will be affected positively. Tata Steel, one of the largest players in the Indian despite this, their economic activity had decreased in 2015 compared to 2014.

Copy Right, IJAR, 2017,. All rights reserved.

\section{Introduction:-}

Tata Steel Limited is an Indian multinational steel-making company headquartered in Mumbai, Maharashtra, India. A subsidiary of the Tata Group, it has a total number of 79,657 employees (2015) and incurs revenues of US\$ 20 billion or 135,278 Crore rupees. Tata Steel's larger production facilities comprise those in India, the UK, the Netherlands, Thailand, Singapore, China and Australia. Operating companies within the Group include Tata Steel Limited (India), Tata Steel Europe Limited (formerly Corus), Tata Steel Singapore and Tata Steel Thailand. Tata Steel's competitors consist of JSW steel, SAIL and Jindal industries, all major contributors in the steel industry.

Corresponding Author:- Deepa Chavan.

Address:- Assistant Professor, Sydenham Institute of Management Studies, Research and Entrepreneurship Education, Mumbai, India. 
The Tata Steel Group's vision is to be the world's steel industry benchmarks in "Value Creation" and "Corporate Citizenship" through the excellence of its people, its innovative approach and overall conduct. Underpinning this vision is a performance culture committed to aspiration targets, safety and social responsibility, continuous improvement, openness and transparency. In 2008, Tata Steel India became the first integrated steel plant in the world, outside Japan, to be awarded the Deming Application Prize 2008 for excellence in Total Quality Management. In 2012, Tata Steel became the first integrated steel company in the world, outside Japan, to win the Deming Grand Prize 2012 instituted by the Japanese Union of Scientists and Engineers (Tata Steel 2016).

\section{Literature review}

The ratio data has been taken from Moneycontrol.com, a reputed and sought after source of information related to finance and business in India. However, this paper is not being analytical about the steel industry in India and is only considering one big player (Tata Steel). Our study of the company is also limited as we only consider data from the most recent 3 years of the company's activities. All definitions of ratio's as well as their interpretation have been taken from the book Introduction to Managerial Accounting (Brewer, Garrison and Noreen 2016).

As said by Florenz Tugas, most financial statement analyses focus on firms belonging to industries that either contributes significantly to economic figures or post it in a highly competitive business environment. Whatever the motivation may be, financial statement analysis should be made available to all industries for reasons of comparability and benchmarking (Tugas 2012). In addition, empirical results of a financial statement can be used to adequately signal business failure in the context of normal economic circumstances (Tuvadaratragool 2013). According to Savchuk, liquidity is one of the most essential factors for assessing the company's position (Savchuk 2014).

\section{Limitations of research:-}

- The paper analyzes only one company from the steel industry.

- Restricted study from year 2014 to year 2015.

- Secondary information from online resources.

\section{Research methodology:-}

All research used for this paper will be secondary information. A trusted Indian online source, Moneycontrol.com (Money Control 2016), used by seasoned professionals as well as stock brokers is the source of the secondary research and information employed in this paper. Secondary information was also used from Tatasteel.com. The method of analysis is through ratios. The study concentrates on profitability ratios and concentrates on company's two-year growth (Kothari and Garg 2015).

\section{Data Analysis \& Findings:-}

Liquidity Ratios:-

$\mathbf{H}_{(\mathbf{0})}$ : There is no significant difference in the liquidity ratios in year 2014 and 2015

$\mathbf{H}_{(\mathbf{1})}$ : There is significant difference in the liquidity ratios in year 2014 and 2015

Table (1):- Descriptive Statistics

\begin{tabular}{|l|l|l|l|}
\hline Liquidity Ratios & Mar'15 & Mar'14 & Industry Standard \\
\hline Current Ratio & 0.52 & 0.62 & $2: 1$ \\
\hline Quick Ratio & 0.32 & 0.27 & $1: 1$ \\
\hline
\end{tabular}

\section{Current Ratio:-}

$\mathbf{H}_{(\mathbf{0})}$ a: There is no significant difference in the liquidity ratios in year 2014 and 2015

$\mathbf{H}_{(\mathbf{1})}$ a: There is significant difference in the liquidity ratios in year 2014 and 2015

In the table above, the industry standard is mentioned. However when we look at Tata Steel's ratios, we see that their current ratio is lower than the standard. A relatively low current ratio represents that the liquidity position of the firm is not good and the firm shall not be able to pay its current liabilities in time without facing difficulties.

As we can see, the current ratio should be 2, where as Tata's is 0.62 in March 2014 and decreases to 0.52 in March 2015. The decrease will affect Tata negatively. This could be due to many reasons, some being insufficient funds to pay off liabilities or the business trading beyond its capacity. In the case of Tata's current ratio, hypotheses H (1) a, proves to be applicable as there is significant difference in the liquidity ratios in year 2014 and 2015. 


\section{B) Quick Ratio}

$\mathbf{H}_{(\mathbf{0})}$ b: There is no significant difference in the liquidity ratios in year 2014 and 2015

$\mathbf{H}_{(\mathbf{1})} \mathbf{b}$ : There is significant difference in the liquidity ratios in year 2014 and 2015

On the other hand, Quick ratio should be 1. Tata's quick ratio is low at a 0.27 in March 2014 and 0.32 in March 2015, however there is an increase when year 2014 is compared to year 2015. This increase will have a positive affect on the overall function and business activity of Tata. This could be because Tata is meeting its short-term obligations in time because of its very efficient inventory management. In the case of Tata's quick ratio, hypotheses $\mathrm{H}_{(1)} \mathrm{b}$ proves to be applicable as there is significant difference in the liquidity ratios in year 2014 and 2015.

After looking at the balance sheets of Tata we can make some assumptions for why this effect might have occurred. Cash and bank Balances reduced from 961.16 crore rupees in 2014 to 478.59 crore rupees in 2015. Their cash flow has been affected and reduced; this might have an effect on the liquidity ratio as 'liquidity' of the company has reduced. A step toward improving the ratios could be that of increase liquidity or the inflow and outflow of cash. In the case of Tata's Liquidity ratios, hypotheses $H_{(1)}$ proves to be applicable as there is significant difference in the liquidity ratios in year 2014 and 2015.

\section{Profitability Ratios:-}

$\mathbf{H}_{(\mathbf{0})}$ : There is no significant difference in the liquidity ratios in year 2014 and 2015

$\mathbf{H}_{(\mathbf{1})}$ : There is significant difference in the liquidity ratios in year 2014 and 2015

Table (2):- Descriptive Statistics

\begin{tabular}{|l|l|l|}
\hline Profitability Ratios & Mar'15 & Mar'14 \\
\hline Operating Profit Margin (\%) & 18.87 & 23.95 \\
\hline Gross Profit Margin (\%) & 13.81 & 19.17 \\
\hline Net Profit Margin (\%) & 12.82 & 15.41 \\
\hline Return On Capital Employed (\%) & 9.03 & 9.25 \\
\hline
\end{tabular}

\section{Gross Profit Ratio:-}

$\mathbf{H}_{(\mathbf{0})}$ a: There is no significant difference in the liquidity ratios in year 2014 and 2015

$\mathbf{H}_{(\mathbf{1})}$ a: There is significant difference in the liquidity ratios in year 2014 and 2015

Gross profit is very important for any business. It should be sufficient to cover all expenses and provide for profit.

There is no norm or standard to interpret gross profit ratio. Generally, a higher ratio is considered better. To judge whether the ratio is satisfactory or not, it should be compared with its own past ratios.

A consistent improvement in gross profit ratio over the past years is the indication of continuous improvement. However as we see above, Tata's gross profit has fallen from $19.17 \%$ in 2014 to $13.81 \%$ in 2015 . This could have occurred due to a decrease in overall sales volume caused by a decrease in units sold or decreased selling prices or due to an increase in purchasing costs that is not offset by an increase in selling prices. For Tata's gross profit, hypotheses $\mathrm{H}(1) \mathrm{b}$ is applicable as there is a negative change.

\section{Operating Ratio:-}

$\mathbf{H}_{(\mathbf{0})}$ b: There is no significant difference in the liquidity ratios in year 2014 and 2015

$\mathbf{H}_{\text {(1) }}$ b: There is significant difference in the liquidity ratios in year 2014 and 2015

This ratio is used to measure the operational efficiency of the management. It shows whether the cost component in the sales figure is within normal range. A low operating ratio means high net profit ratio i.e., more operating profit. To judge whether the ratio is satisfactory or not, it should be compared with its own past ratios.

As shown above, Tata's operating ratio has fallen from $23.95 \%$ in 2014 to $18.87 \%$ in 2015 . This reduction could be due to either a decrease in sales or an increase in expenses.

Net Profit Ratio:-

$\mathbf{H}_{(\mathbf{0})}$ ): There is no significant difference in the Net Profit Ratio in year 2014 and 2015

$\mathbf{H}_{\text {(1) }}$ c: There is significant difference in the Net Profit Ratio in year 2014 and 2015 
For the purpose of this ratio, net profit is equal to gross profit minus operating expenses and income tax. All nonoperating revenues and expenses are not taken into account because the purpose of this ratio is to evaluate the profitability of the business from its primary operations. To judge whether the ratio is satisfactory or not, it should be compared with its own past ratios.

As shown above, Tata's operating ratio has fallen from $23.95 \%$ in 2014 to $18.87 \%$ in 2015 . This reduction could be due to either a decrease in sales or an increase in expenses.

Return on Capital Employed/ Return on Investment:-

$\mathbf{H}_{(\mathbf{0})}$ d: There is no significant difference in the Return on Capital Employed in year 2014 and 2015

$\mathbf{H}_{(\mathbf{1})} \mathbf{d}$ : There is significant difference in the Return on Capital Employed in year 2014 and 2015

Return on capital employed ratio measures the efficiency with which the investment made by shareholders and creditors is used in the business. Managers use this ratio for various financial decisions. It is a ratio of overall profitability and a higher ratio is, therefor, better.

As shown above, Tata's Return On Capital Employed has fallen from 9.25\% in 2014 to $9.03 \%$ in 2015. For this case, hypotheses $\mathrm{H}(0) \mathrm{d}$ is applicable as there is no significant difference in the Return On Capital Employed. This is a positive sign as their return on investment has not changed much. This keeps all stakeholders feeling secure and confident.

\section{Conclusion:-}

As shown in the analysis above, Tata Steel, one of the largest players in the Indian steel market has suffered some fallbacks. However, the company has made an effort to maintain their stance in the market and have been successful in doing so. Despite this, their economic activity had decreased in 2015 compared to 2014 . This could be due to a few reasons, as mentioned above. Tata needs to take some steps in moving forward as their growth slows down and is hampered. Tata Steel exports $67 \%$ of their revenue and should work on the untapped domestic market by being more competitive. Though Tata Steel's revenues from the domestic market are 32\%, this figure can be increased, leading to higher sales revenue and eventually higher profits. Tata also needs to concentrate on reducing their expenses and seen above and in their other financial statements, as expenses eat away at the company's profits quite largely.

\section{Bibliography:-}

1. Brewer, Peter c, Ray H Garrison, and Eric w Noreen. Introduction to Managerial Accounting . Washington: McGrawHill Education , 2016.

2. Tugas, Florenz C. "A Comparative Analysis of the Financial Ratios of Listed Firms Belonging to the Education Subsector in the Philippines for the Years 2009-2011." International Journal of Business and Social Science 3, no. 21 (November 2012): 180-181.

3. Tuvadaratragool, Sumeth. "The role of financial ratios in signalling financial distress: evidence from Thai listed companies." Southern Cross University, 2013: 9-14.

4. Savchuk, Olena. "Liquidity Analysis of a Company." Skemman, 2014: 1-5.

5. Tata Steel. Tatasteel.com. march 15, 2016. http://www.tatasteel.com/about-us/company-profile.asp.

6. Kothari, C.R, and Gaurav Garg. Research Methodology: Methods and Techniques . India, 2015.

7. Money Control. Moneycontrol.com. november 24, 2016. Moneycontrol.com.

8. Ministry of Steel, Government of India. Ministry of Steel. november 24, 2016. http://steel.nic.in/overview.htm. 